\title{
Large-scale Mapping of Arctic Coastal Infrastructure using Copernicus Sentinel Data and Machine Learning and Deep Learning Methods
}

\author{
Pointner, Georg ; Bartsch, Annett ; Ingeman-Nielsen, Thomas
}

Link to article, DOI:

https://doi.org/10.5194/egusphere-egu2020-8978

Publication date:

2020

Document Version

Publisher's PDF, also known as Version of record

Link back to DTU Orbit

Citation $(A P A)$ :

Pointner, G., Bartsch, A., \& Ingeman-Nielsen, T. (2020). Large-scale Mapping of Arctic Coastal Infrastructure using Copernicus Sentinel Data and Machine Learning and Deep Learning Methods. Abstract from EGU General Assembly 2020. https://doi.org/10.5194/egusphere-egu2020-8978

\section{General rights}

Copyright and moral rights for the publications made accessible in the public portal are retained by the authors and/or other copyright owners and it is a condition of accessing publications that users recognise and abide by the legal requirements associated with these rights.

- Users may download and print one copy of any publication from the public portal for the purpose of private study or research.

- You may not further distribute the material or use it for any profit-making activity or commercial gain

- You may freely distribute the URL identifying the publication in the public portal 
EGU2020-8978

https://doi.org/10.5194/egusphere-egu2020-8978

EGU General Assembly 2020

(c) Author(s) 2020. This work is distributed under

the Creative Commons Attribution 4.0 License.

\title{
Large-scale Mapping of Arctic Coastal Infrastructure using Copernicus Sentinel Data and Machine Learning and Deep Learning Methods
}

\author{
Georg Pointner ${ }^{1,2}$, Annett Bartsch ${ }^{1,2}$, and Thomas Ingeman-Nielsen ${ }^{3}$ \\ ${ }^{1}$ b.geos GmbH, Korneuburg, Austria (pointner@bgeos.com) \\ ${ }^{2}$ Austrian Polar Research Institute, Vienna, Austria \\ ${ }^{3}$ Department of Civil Engineering, Technical University of Denmark, Lyngby, Denmark
}

The climate change induced increased warming of the Arctic is leading to an accelerated thawing of permafrost, which can cause ground subsidence. In consequence, buildings and other infrastructure of local settlements are endangered from destabilization and collapsing in many Arctic regions. The increase of the exploitation of Arctic natural resources has led to the establishment of large industrial infrastructures that are at risk likewise. Most of the human activity in the Arctic is located near permafrost coasts. The thawing of coastal permafrost additionally leads to coastal erosion, which makes Arctic coastal settlements even more vulnerable.

The European Union (EU) Horizon2020 project "Nunataryuk" aims to assess the impacts of thawing land, coast and subsea permafrost on the climate and on local communities in the Arctic. One task of the project is to determine the impacts of permafrost thaw on coastal Arctic infrastructures and to provide appropriate adaptation and mitigation strategies. For that purpose, a circumpolar account of infrastructure is needed.

During recent years, the two polar-orbiting Sentinel-2 satellites of the Copernicus program of the EU have been acquiring multi-spectral imagery at high spatial and temporal resolution. Sentinel-2 data is a common choice for land cover mapping. Most land cover products only include one class for built-up areas, however. The fusion of optical and Synthetic Aperture Radar (SAR) data for land cover mapping has gained more and more attention over the last years. By combining Sentinel-2 and Sentinel-1 SAR data, the classification of multiple types of infrastructure can be anticipated. Another emerging trend is the application machine learning and deep learning methods for land cover mapping.

We present an automated workflow for downloading, processing and classifying Sentinel-2 and Sentinel-1 data in order to map coastal infrastructure with circum-Arctic extent, developed on a highly performant virtual machine (VM) provided by the Copernicus Research and User Support (RUS). We further assess the first classification results mapped with two different methods, one being a pixel-based classification using a Gradient Boosting Machine and the other being a 
windowed semantic segmentation approach using the deep-learning framework keras. 